\title{
ANALISIS PENATAAN ASET TETAP PADA BADAN PENGELOLAAN KEUANGAN DAN ASSET DAERAH KOTA JAYAPURA
}

\author{
Maranatha Siregar \\ natexduadua@gmail.com \\ Westim Ratang \\ westim ratang@yahoo.co.id \\ Syaikhul Falah \\ sehufalah@gmail.com
}

\begin{abstract}
One of the problems that often arise in the management of regional property is the administration of regional property. In the implementation of the Asset Administration, it is often constrained in terms of reporting the assets of certain Regional Apparatus Organizations. This is because there is no Standard Operating Procedure in terms of the Administration of these Assets, which causes delays in the preparation of Regional Government Financial Reports (LKPD). The causes of administrative side problems are incomplete documents and unclear deletion findings, financial side causes, namely budget constraints, delegation and misuse of maintenance costs, causes of bureaucracy, namely the absence of a legal umbrella, limited responsibilities of BPKAD, non-centralized procurement of vehicles, causes of human resources namely the level of employee mutation and limited human resources and the causes of limitations in the use of regional property management information systems, namely SIMDA BMD still using an off-line system and SIMDA BMD in the City Government of Jayapura has not been integrated into the financial department of BPKAD.
\end{abstract}

Keywords: Bookkeeping, Inventory, Reporting

\section{PENDAHULUAN}

Sejak diberlakukannya (Undang-Undang Nomor 23 Tahun 2014 Tentang Pemerintah Daerah, 2014) tentang Pemerintah Daerah, politis dan administratif menghadapi pergeseran fundamental. Maka penataan manajemen pemerintahan yang dapat bekerja secara lebih efisien, efektif dan ekonomis, sangat diperlukan untuk menghadapi perubahan pengelolaan pemerintah daerah tersebut Terdapat 12 masa manfaat asset tetap atau asset berwujud yang dibunyikan dalam Peraturan Pemerintah tahun 2010 demi kepentingan umum yaitu: (1) Tanah, (2) Peralatan dan Mesin, (3) Gedung dan Bangunan, (4) Jalan, Irigasi dan Jaringan, (5) Aset tetap lainnya dan (6) Konstruksi dalam pengerjaan. Aset tanah merupakan aset yang paling rawan terjadi penyerobotan dari sekian aset yang dimiliki oleh pemerintah 
daerah tersebut.

Disebutkan dalam pasal 1 butir 11 UU No 1 Tahun 2004 tentang Perbendaharaan Negara, Barang Milik Daerah (BMD) ialah semua barang yang dibeli atau diperoleh atas beban APBD atau berasal dari perolehan lainnya yang sah". Pada hakekatnya BMD digunakan dalam penyelenggaraan tugas pokok dan fungsi kementerian negara/lembaga/OPD.

Laporan keuangan yang disusun melalui suatu proses akuntansi atas transaksi keuangan, aset, hutang, ekuitas dana, pendapatan dan belanja, termasuk transaksi pembiayaan dan perhitungan merupakan pertanggungjawaban atas pemakaian barang milik daerah wajib dilaporkan oleh Pemerintah melalui pertanggungjawaban atas pelaksanaan Anggaran Pendapatan dan Belanja Daerah (APBD). Salah satu komponen yang paling strategis dalam pengelolaan keuangan daerah ialah Aset Tetap. Keberadaan aset tetap sangat mempengaruhi kelancaran roda pemerintahan dan pembangunan karena nilai aset tetap daerah merupakan nilai yang paling besar dibandingkan dengan akun lain pada laporan keuangan. Penataan manajemen aset hanyalah serangkaian bagian dari sistem pengelolaan, sehingga dalam penelitian nantinya tidak bias dengan Pengelolaan aset daerah diatur dalam (PP No.6/2006 Tentang Pengelolaan Barang Milik Daerah, 2006) tentang Pengelolaan Barang Milik Daerah, yang kemudian ditindaklanjuti dengan (Peraturan Menteri Dalam Negeri Nomor 17 Tahun 2007 Tentang Pedoman Teknis Pengelolaan Barang Milik Daerah, 2007). Oleh karena itu, sistem pengendalian intern atas manajemen/pengelola aset tetap daerah harus handal untuk mencegah penyimpangan yang dapat merugikan keuangan daerah 


\section{LANDASAN TEORI DAN PENGEMBANGAN HIPOTESIS}

\section{Manajemen Asset}

Secara umum dijabarkan sebagai serangkaian proses yang dikaitkan dengan identifikasi aset apa yang dibutuhkan, bagaimana cara mendapatkannya, cara membantu dan memeliharanya, serta cara menghilangkan atau memperbaruinya sehingga aset tersebut secara efektif dan efisien dapat mewujudkan sasaran/objektif. Sedangkan manajemen aset secara khusus diartikan serangkain disiplin, metode, prosedur, dan tool untuk optimalkan dampak seluruh bisnis atas biaya, kinerja dan uraian resiko (terkait dengan ketersediaan, efisiensi, umur pakai, dan regulasi /keselamatan / taat pada aturan lingkungan hidup) dari aset fisik perusahaan.

Secara tidak langsung, manfaat dari Manajemen Aset (Siregar, 2004) itu sendiri adalah:

- Menolong organisasi untuk mengamati dan menilai kekayaan; perkakas, perangkat keras dan lunak, peralatan kantor, peralatan mesin, mesin.

- Memudahkan perusahaan untuk menyimpan; daftar kekayaan, dokumen pembelian secara berturut-turut, biaya-biaya, jumlah, lokasi, digunakan oleh siapa, pelayanan, inventaris dan perhitungan asuransi, akumulasi depresiasi dan nilai yang berlaku sekarang.

- Mempermudah administrasi dari aset dan hubungannya dengan tugas pencatatan.

Perencanaan aset (asset planning) mencakup konfirmasi pelayanan yang dibutuhkan oleh pelanggan dan memastikan bahwa aset yang diusulkan merupakan penanggulangan paling efektif untuk memenuhi keperluan pelanggan. Penciptaan/Pengadaan aset adalah peningkatan aset di mana pembiayaan dapat menjadi alasan yang diharapkan memberikan manfaat di luar tahun buku 
Pemanfaatan aset memiliki peranan penting yang berkaitan dengan pekerjaan, pengendalian aset dan biaya yang terkait dengannya, yang merupakan komponen terpenting dalam aset dinamis atau jangka pendek. Penghapusan aset (asset disposal) ialah jika suatu asset sudah tidak mempunyai nilai ekonomis untuk dirawat atau direhabilitasi sehingga asset tersebut tidak lagi diperlukan.

Berdasarkan definisi dapat diuraikan bahwa untuk mendukung suatu organisasi dalam mencapai tujuan yang telah ditetapkan sebelumnya kegiatan pengelolaan suatu barang yang memiliki nilai dan manfaat yang dapat digunakan disebut dengan Manajemen Aset. Dalam mengelola aset, setiap proses atau fungsi yang ada perlu diawasi oleh organisasi atau kementerian / lembaga. Pengawasan penhgelolaan aset selama kehidupan ekonomi bertujuan untuk menjaga aset agar dapat membantu proses pencapaian tujuan individu atau organisasi pemilik aset.

Ada lima tujuan pengelolaan aset. Tujuan-Tujuan pengelolaan aset antara lain;

a. kejelasan status kepemilikan aset

inventarisasi kekayaan daerah dan umur aset, optimalisasi pemanfaatan untuk menambah pendapatan, pengamanan aset dan sumber penyusunan neraca, untuk lebih jelasnya lihat di bawah ini: Kejelasan kepemilikan aset status Asset management salah satunya dilakukan dengan cara melakukan legal audit terhadap suatu aset, sehingga dapat diketahui secara jelas kepemilikan aset tersebut. Hal ini untuk menghindarkan kepemilikan ganda dari satu aset.

b. Inventarisasi kekayaan daerah dan masa pakai asset

Aset yang sudah diketahui secara jelas status kepemilikannya dapat diinventarisasikan sesuai dengan status kepemilikannya. Apabila aset itu milik negara maka akan di inventarisasi sebagai kekayaan negara, apabila aset itu 
milik pemerintah daerah maka aset tersebut akan di inventarisasi sebagai kekayaan daerah. Selain itu akan diketahui masa pakai dan umur ekonomis dari aset tersebut.

c. Optimasi penggunaan dan pemanfaatan untuk peningkatan pendapatan.

Aset yang berstatus idle capacity dapat dimanfaatkan dengan baik sesuaidengan peruntukkan yang ditetapkan sehingga dapat diketahui pemanfaatannya untuk apa, peruntukkan dari aset tersebut kepada siapa, danmampu mendatangkan pendapatan bagi pengelola aset.

d. Pengamanan aset

Aset yang dimiliki oleh individu atau pemerintah dapat diamankan dengan baik karena telah di lakukan inventarisasi, sehingga aset tersebut tidak akan mudah jatuh ke tangan orang lain. Apabila ada yang mengakui memiliki aset tersebut maka dapat dibuktikan secara hukum.

e. Dasar penyusunan neraca

Aset yang sudah diketahui secara jelas kepemilikannya akan dapat diperhitungkan dalam dasar penyusunan neraca sebagai jumlah kekayaan yang dimiliki baik oleh negara maupun daerah.

Berdasarkan pendapat di atas secara umum tujuan dari pengelolaan aset ini adalah membantu suatu entitas (organisasi) dalam memenuhi tujuan penyediaan pelayanan secara efektif dan efisien. Hal ini mencakup perencanaan, panduan pengadaan, penggunaan, penghapusan aset dan pengaturan risiko serta biaya yang terkait selama siklus hidup aset.

\section{Penataan Aset Tetap}

Dalam rangka mewujudkan tertib administrasi terhadap pengelolaan barang 
daerah perlu diatur pedoman kerjanya, untuk itu telah dikeluarkan (Peraturan Menteri Dalam Negeri Nomor 19 Tahun 2016 Tentang Pedoman Teknis Pengelolaan Barang Milik Daerah, 2016) (pembaruan Permendagri No. 17 Tahun 2007). Dalam Peraturan Menteri Dalam Negeri tersebut dimaksud dengan Barang Milik Daerah adalah semua barang yang dibeli atau diperoleh atas beban Anggaran Pendapatan dan Belanja Daerah atau perolehan lainnya yang sah.

Pengelolaan Aset Tetap, Pengelolaan barang milik daerah merupakan bagian dari pengelolaan keuangan daerah. Selain itu, barang milik daerah merupakan salah satu unsur penting dalam rangka penyelenggaran pemerintahan dan pelayanan kepada masyarakat. Oleh karena itu, pengelolaan barang milik daerah yang baik akan mencerminkan pengelolaan keuangan daerah yang baik. Tentu saja pengelolaan barang milik daerah harus dilakukan dengan baik dan benar.

Pengelolaan aset negara Pasal 1 Ayat (1) dan Ayat (2) PP No. 27 Tahun 2014 adalah tidak sekedar administrative semata, tetapi lebih maju berfikir dalam menangani aset negara, dengan bagaimana meningkatkan efisiensi, efektifitas dan menciptakan nilai tambah dalam mengelola aset. Oleh karena itu, lingkup pengelolaan aset Negara mencakup perencanaan kebutuhan dan penganggaran, pengadaan, penggunaan, pemanfaatan, pengamanan dan pemeliharaan, penilaian, penghapusan, pemindahtanganan, penatausahaan, pembinaan, pengawasan, dan pengendalian.

\section{Teori NPM (New Public Management)}

Pergeseran paradigma dalam ilmu administrasi publik seperti dalam pandangan yang dikemukakan (Denhardt, 2003), bahwa administrasi publik telah berfungsi sebagai "the larger system of democratic governance", yang memunculkan pemikiran baru yang mengarah kepada perubahan pola penyelenggaraan 
pemerintahan, yaitu dari pola tradisional atau konvensional menjadi pola baru penyelenggaraan pemerintahan yang melibatkan kolaborasi antara pemerintah, dengan swasta dan masyarakat.

Para pakar berpandangan, perubahan pola penyelenggaraan pemerintahan seperti itu berawal dari konsep pemerintah (government) menjadi kepemerintahan (governance) sebagai wujud interaksi sosial politik antara pemerintah dengan masyarakat dalam menghadapi berbagai kontemporer yang demikian kompleks, dinamis, dan beraneka ragam. Konsep governmnet menurut (Keban, 2008), mengindikasikan pengertian dari sisi administrasi publik sebagai birokrasi klasik ala Weber dengan fokus "struktur organisasi dan fungsi" atau prinsip-prinsip manajemen, sedangkan yang merupakan lokusnya adalah pemerintahan yang bertujuan untuk mewujudkan efisiensi, efektivitas, dan rasionalitas.

\section{METODOLOGI PENELITIAN}

Jenis penelitian yang dilakukan oleh penulis adalah lapangan (field research) peneliti menggunakan jenis penelitian campuran/ kombinasi (mixed methodology). Mixed method menghasilkan fakta yang lebih komprehensif dalam meneliti masalah penelitian, karena peneliti ini memiliki kebebasan untuk menggunakan semua alat pengumpul data sesuai dengan jenis data yang dibutuhkan. Sedangkan kuantitatif atau kualitatif hanya terbatas pada jenis alat pengumpul data tertentu saja. Mixed Methods Research adalah suatu desain penelitian yang didasari asumsi filosofis sebagaimana metoda inkuiri.

Pendekatan ini melibatkan asumsi-asumsi filosofis, aplikasi pendekatanpendekatan kualitatif dan kuantitatif, serta pencampuran (mixing) kedua pendekatan tersebut dalam satu penelitian. Pendekatan ini lebih kompleks dari sekadar mengumpulkan dan menganalisis dua jenis data; tetapi juga melibatkan fungsi dari 
dua pendekatan penelitian tersebut secara kolektif sehingga kekuatan penelitian ini secara keseluruhan lebih besar daripada penelitian kualitatif dan kuantitatif.

Penelitian deskriptif ini merupakan penelitian yang tidak dimaksudkan untuk menguji hipotesis tertentu tetapi hanya menggambarkan apa adanya tentang sesuatu variabel, gejala atau keadaan. Pengumpulan data dengan melukiskan sebagaimana adanya, tidak diiringi dengan ulasan atau pandangan atau analisis dari penulis.

\section{HASIL PENELITIAN DAN PEMBAHASAN}

Hasil Wawancara Wawancara dilakukan dengan informan yang dinilai memahami tentang penatausahaan aset tetap kendaraan dinas melalui Sistem Informasi Manajemen Barang Milik Daerah (SIMDA BMD) pada Badan Pengelola Keuangan dan Aset Daerah Pemerintah Kota Jayapura. Selama proses wawancara berlangsung, penulis merekam hasil wawancara dengan menggunakan alat perekam dan membuat catatan-catatan.

Tabel 4.1 Informan Wawancara dan Kode Informan

\begin{tabular}{|c|c|l|}
\hline No. & Kode & \\
\hline 1 & IP1 & Kepala Inspektorat \\
\hline 2 & IP2 & Sekretaris BPKAD \\
\hline 3 & IP3 & Kepala Bidang Aset \\
\hline 4 & IP4 & Kasubbid Analisa Pengadaan dan Distribusi \\
\hline 5 & IP5 & Kasubbid Analisa Kebutuhan dan Inventarisasi \\
\hline
\end{tabular}

Sumber: Diolah

Proses pertama dalam menganalisis data hasil wawancara yaitu menulis transkip hasil wawancara. Tabel 4.1 merupakan tabel informan dan kode informan. Pemberian kode informan dimaksudkan untuk memudahkan penyebutan informan dan penjagaan kerahasiaan indenitas informan yaitu 2 (dua) huruf dan 1 (satu) angka. Kode "IP" menunjukkan singkatan dari "informan penelitian". Angka 1-5 menunjukkan urutan nomor informan berdasarkan waktu melakukan wawancara.

Hasil transkip wawancara menunjukkan tidak semua jawaban informan 
terkait dengan rumusan masalah dalam penelitian ini. Oleh karena itu, dilakukan proses reduksi data untuk memilih data yang memiliki kesesuaian dengan fokus dan masalah penelitian. Reduksi data dilakukan dengan menggunakan analisis tematik. Tahapan reduksi data adalah memberikan kategori dan nama tema berdasarkan pada kesamaan makna kategori. Tiap kategori yang telah dikelompokan, disusun membentuk subtema. Hasil subtema tersebut kemudian diklasifikasikan ke dalam tema-tema. Tahapan pasca reduksi data adalah menyajikan data dalam pembahasan. Penyajian data dilakukan dengan memperhatikan hasil reduksi data dan kesadaran akan tulisan yang baik dan benar sehingga dapat memastikan konsistensi keterbacaan penulisan karya tulis ini. Tabel 4.2 merupakan tabel penyajian data dalam penelitian ini. Penulisan pembahasan akan disusun berdasarkan tabel penyajian data dalam penelitian ini. Penulisan pembahasan akan disusun berdasarkan tabel penyajian data di bawah ini.

Tabel 4.2 Penyajian Data

\begin{tabular}{|c|c|c|c|}
\hline No & Tema & Subtema 1 & Subtema 2 \\
\hline \multirow{28}{*}{1} & \multirow{28}{*}{$\begin{array}{l}\text { Penatausahaan Aset } \\
\text { Tetap Kendaraan } \\
\text { Dinas }\end{array}$} & \multirow{9}{*}{ Pembukuan } & Pembukuan KIB \\
\hline & & & Pedoman Pengelolaan BMD \\
\hline & & & Pencatatan Bukti Kepemilikan \\
\hline & & & SIMDA BMD \\
\hline & & & Pencatatan sesuai spesifikasi \\
\hline & & & Analisis data kendaraaan dinas \\
\hline & & & Kodefikasi barang \\
\hline & & & Dokumen kontrak \\
\hline & & & Kelengkapan dokumen \\
\hline & & \multirow{18}{*}{ Inventarisasi } & Upaya penarikan \\
\hline & & & Pembinaan \\
\hline & & & Pengelolaan Kendaraan dinas \\
\hline & & & $\begin{array}{l}\text { Rekapitulasi kebutuhan kendaraan } \\
\text { dinas }\end{array}$ \\
\hline & & & Dokumen kendaraan hibah \\
\hline & & & Pengamanan dan pengawasan \\
\hline & & & Dokumen BKPB dan STNK \\
\hline & & & Biaya pemeliharaan \\
\hline & & & Pelaksanaan sensus \\
\hline & & & Perencanaan kendaraan dinas \\
\hline & & & Berita acara dan NPHD \\
\hline & & & Buku inventaris dan induk inventaris \\
\hline & & & Peran BPK dan Inspektorat \\
\hline & & & Penghapusan \\
\hline & & & Pengadaan dan pendistribusian \\
\hline & & & E-Katalog \\
\hline & & & Standar harga kendaraan dinas \\
\hline & & & Pemusatan kendaraan dinas \\
\hline & & Pelaporan & Pelaporan barang milik daerah \\
\hline
\end{tabular}




\begin{tabular}{|c|c|c|c|}
\hline & & & Laporan pengurus barang \\
\hline \multirow{12}{*}{2} & \multirow{12}{*}{$\begin{array}{l}\text { Penyebab } \\
\text { Permasalahan Aset } \\
\text { Tetap Kendaran } \\
\text { Dinas }\end{array}$} & \multirow{2}{*}{ Administrasi } & Ketidaklengkapan dokumen \\
\hline & & & Ketidakjelasan temuan penghapusan \\
\hline & & \multirow{3}{*}{ Keuangan } & Keterbatasan Anggaran \\
\hline & & & $\begin{array}{l}\text { Pelimpahan dan penyalahgunaan } \\
\text { anggaran biaya pemeliharaan }\end{array}$ \\
\hline & & & $\begin{array}{l}\text { Penunggakan pembayaran penjualan } \\
\text { kendaraan dinas }\end{array}$ \\
\hline & & \multirow{3}{*}{ Birokrasi } & Ketiadaan payung hukum \\
\hline & & & Keterbatasan tanggung jawab BPKAD \\
\hline & & & $\begin{array}{l}\text { Pengadaan kendaraan yang tidak } \\
\text { terpusat }\end{array}$ \\
\hline & & \multirow{2}{*}{$\begin{array}{l}\text { Sumber Daya } \\
\text { Manusia }\end{array}$} & Tingkat mutasi pegawai \\
\hline & & & Keterbatasan Sumber Daya Manusia \\
\hline & & \multirow{2}{*}{ Sistem Informasi } & $\begin{array}{l}\text { SIMDA BMD masih menggunakan } \\
\text { sistem off-line }\end{array}$ \\
\hline & & & $\begin{array}{l}\text { SIMDA BMD tidak terintegrasi dengan } \\
\text { bagian keuangan }\end{array}$ \\
\hline
\end{tabular}

Sumber: Diolah

Penyajian data akan dilakukan sesuai dengan tabel 4.2 di atas. Untuk memudahkan penelusuran sumber data hasil wawancara, setiap data yang disajikan diberikan kode informan dan urutan baris dalam hasil transkip wawancara.

\section{Pembahasan}

Seperti telah dijelaskan dalam (Peraturan Menteri Dalam Negeri Nomor 19 Tahun 2016) tentang Pedoman Teknis Pengelolaan Barang Milik Daerah bahwa salah unsur Penatausahaan Pasal 1 merupakan proses melakukan pembukuan, inventariisasi dan pelaporan barang miilik daerah sesuaii dengan ketentuan peraturan perunndang-undangan. Dalam pelaksanaan Proses Penatausahaan pada Pemerintah Kota Jayapura sering terkendala pada hal-hal teknis terkhususnya di penerapannya di lapangan.

\section{Penatausahaan Aset Tetap berupa Kendaraan Dinas Kota Jayapura menggunakan aplikasi SIMDA Barang Milik Daerah}

Badan Pengelolaa Keuangan dan Aset Daerah (BPKAD) Kota Jayapura sebagai badan keuangan yang bertangggung jawab atas penatausahaan aset tetap berupa kendaraan dinas, melakukan kegiatan penatausahaan aset tetap kendaraan dinas dengan melihat permintaan kebutuhan kendaraan dinas dari tiap-tiap OPD 
pada Pemerintah Kota Jayapura.

Penatausahaan aset tetap kendaraan dinas menggunakan program aplikasi SIMDA BMD dalam melakukan proses pengelolaan barang milik daerah secara otomatis dengan memanfaatkan pengelolaan data elektronik. BPKAD selaku pembantu pengelola, salah satu tugasnya adalah menggabungkan daftar barang inventaris seluruh OPD di Pemerintah Kota Jayapura. Proses penggabungan dilakukan melalui eksport import data. Pertama, pengurus barang OPD datang ke BPKAD untuk mengeksport data, lalu petugas SIMDA melakukan import data. SIMDA BMD terdiri dari beberapa menu bar yang merupakan suatu rangkaian yang terkait dengan lainnya. Menu aplikasi tersebut antara lain:

a. File adalah menu yang harus dipilih untuk mongaktifkan aplikasi dengan nama dan password;

b. Parameter adalah menu untuk melakukan maintenance data parameter yang di isi oleh administrator. Menu ini terdiri dari: (1) data umum pemda; (2) unit organisasi; (3) ruang; (4) kode barang; (5) kode rekening; (6) kebijakan penyusutan dan umur, (7) kebijakan akuntansi dan; (8) copy data parameter.

c. Data entry yang terdiri dari :

1) Perencanaan adalah menu pilihan untuk melakukan input data dan proses perencanaan kebutuhan.

2) Pengadaan adalah menu pilihan untuk melakukan input data dan proses pengadaan barang.

3) Penggunaan adalah menu inputan surat keputusan penggunaan aset yang ditetapkan oleh kepala daerah.

4) Penatausahaan adalah menu untuk inputan melakukan perubahan data aset, pemindahan aset antara OPD dan nilai kapitalisasi aset tetap. 
5) Penghapusan adalah menu pilihan untuk melakukan input data penghapusan barang milik daerah.

d. Laporan adalah menu pilihan untuk melakukan preview output dan proses percetakan laporan.

Dilihat dari sistem yang terdapat dalam aplikasi SIMDA BMD tidak memiliki masalah, apabila pengguna melakukan proses penginputan database benar maka sistem aplikasi SIMDA tersebut akan terus berlanjut hingga hasil akhir berupa laporan KIB. Sistem pada aplikasi SIMDA BMD tidak akan berjalan apabila pengguna tidak memiliki database yang lengkap pada saat melakukan penginputan data. Penginputan database yang dilakukan oleh bendahara barang tiap-tiap OPD pada aplikasi SIMDA BMD masih menggunakan sistem off-line dan hasil akhir yang diserahkan kepada BPKAD bagian aset dalam bentuk print out. Berdasarkan peraturan SIMDA BMD dan SIMDA KEUANGAN harus terintegrasi sehingga pengendalian dan pengawasan aset tetap kendaraan dinas lebih tertib dan tidak terjadi manpulasi data. Pada Pemerintah Kota Jayapura akses internet SIMDA BMD belum disosialisasikan oleh BPKAD sehingga bendahara barang tiap-tiap OPD masih menggunakan sistem off-line. Hal ini sesuai dengan pernyataan wawancara Kepala Inspektorat sebagai berikut:

\begin{abstract}
"Terkait sistem "SIMDA BMD" sendiri tidak ada masalah, hanya pada waktu online setengah mati kalau data base yang lama harus input ulang, karena SIMDA BMD hanya menginput per tahun dan baru digunakan tahun 2015, 2016. Sehingga data yang lama harus diminta di keuangan dan dimasukan kembali karena tidak bisa otomatis. Setelah data dimasukan kemudian log in lagi, karena aplikasi ini up date terus baru bisa digunakan dan masih menggunakan sistem off -line, penginputan dilakukan di masing-masing OPD kemudian hasil akhir berupa print out yang diserahkan kepada BPKAD bagian aset. Sehingga kemungkinan manipulasi data masih bisa terjadi karena baru terintegrasi degan bagian aset belum dengan SIMDA BMD Keuangan. (IP1-L256-269) “
\end{abstract}

\title{
Proses Penatausahaan Aset Tetap
}

\section{Pembukuan}

Pembukuan ialah kegiatan yang dilakukan oleh kuasa pengguna/pengguna 
(kepala OPD) dengan pengurus barang (bendahara barang) sebagai penerima aset tetap kendaraan dinas. Berdasarkan penelitian yang dilakukan pada BPKAD Pemerintah Kota Jayapura sudah melakukan kegiatan pembukuan yang didistribusikan oleh BPKAD.

Pemerintah kota jayapura pada tahun 2015 baru menggunakan aplikasi SIMDA BMD untuk melakukan penatausahaan aset tetap kendaraan dinas. Proses penatausahaan aset tetap kendaraan dinas tidak hanya dilakukan oleh BPKAD tetapi dilakukan di OPD yang menerima aset tetap kendaraan dinas dan masing-masing bendahara barang di OPD melakukan penginputan aset tetap kendaraan dinas kedalam aplikasi SIMDA BMD sesuai dengan spesifikasi barang dalam hal ini kendaraan dinas, karena itu merupakan kewajiban bendahara barang untuk mengisi KIB. Selanjutnya hasil dari proses penginputan pembukuan yang dilakukan oleh bendahara masing-masing OPD disampaikan kepada BPKAD khusus bagian aset pada Kasubbid Analisa Kebutuhan dan Inventarisasi. Hal ini sesuai dengan pernyataan wawancara Kabid Aset sebagai berikut:

"Proses penatausahaan itu yang pertama dilakukan di OPD yang bersangkutan, mereka (bendahara barang) mencatat sesuai dengan spesifikasi barang dalam hal ini kendaraan dinas, kemudian bendahara barang masing-masing OPD sampaikan data kepada BPKAD." (IP3_L5356)"

Hal yang sama dikemukakan oleh Kasubbid Analisa Kebutuhan dan Inventarisasi dalam kutipan wawancara sebagai berikut:

"OPD menginput data aset dimasing-masing OPD melalui SIMDA BMD, karena itu merupakan kewajiban bendahara barang untuk mengisi KIB." (IP5-L98-101)"

Tabel 4.3 Hasil Pengukuran Kesesusaian Pembukuan

\begin{tabular}{|l|l|c|c|c|}
\hline No & \multicolumn{1}{|c|}{ Kriteria Pembukuan } & Ada & \multicolumn{1}{|c|}{$\begin{array}{c}\text { Tidak } \\
\text { Sesuai }\end{array}$} & Teknik \\
\hline 1. & BPKAD memiliki daftar pengguna barang. & 1 & & \\
\hline 2. & $\begin{array}{l}\text { Pengurus barang mendaftar dan } \\
\text { mencatat barang milik daerah ke DPB } \\
\text { (Daftar Barang Pengguna). }\end{array}$ & 1 & & \\
\hline 3. & $\begin{array}{l}\text { BPKAD mencatatat pengelolaan dan } \\
\text { kodefikasi barang. }\end{array}$ & 1 & & \\
\hline 4. & Dokumen disimpan oleh Kepala BPKAD. & & 1 & 0 \\
\hline 5. & BPKAD memiliki KIB & 1 & \\
\hline
\end{tabular}




\begin{tabular}{|c|c|c|c|}
\hline 6. & $\begin{array}{l}\text { Dokumen berupa kepemilikan } \\
\text { berupa kendaraan disimpan } \\
\text { pengelola. }\end{array}$ & 1 & \\
\hline 7. & Dokumen kendaraan hibah. & & 0 \\
\hline 8. & $\begin{array}{l}\text { Pengisian KIB oleh pengurus barang } \\
\text { sudah lengkap dan benar. }\end{array}$ & & 0 \\
\hline 9. & $\begin{array}{l}\text { Pengurus barang melakukan pendaftaran } \\
\text { dan pencatatan sesuai dengan format } \\
\text { KIB. }\end{array}$ & & 0 \\
\hline 10. & $\begin{array}{l}\text { KIB menggambarkan semua kendaraan } \\
\text { dinas di masing-masing OPD. }\end{array}$ & & 0 \\
\hline 11. & $\begin{array}{l}\text { Pengurus barang melakukan koordinasi } \\
\text { dengan pembantu pengelola (bidang } \\
\text { aset) dengan pencatatan dan } \\
\text { pendaftaran BMD di KIB dalam daftar } \\
\text { BMD tepat waktu. }\end{array}$ & 1 & \\
\hline 12. & $\begin{array}{l}\text { Pembantu pengelola (bidang aset) } \\
\text { memiliki rekapitulasi KIB. }\end{array}$ & 1 & \\
\hline 13. & $\begin{array}{l}\text { Pembantu pengelola (bidang aset) } \\
\text { melakukan pendaftaran dan pencatatan } \\
\text { BMD menurut pengelola barang dan } \\
\text { kodefikasi barang. }\end{array}$ & 1 & \\
\hline & Jumlah Kriteria & 8 & 5 \\
\hline
\end{tabular}

\section{Sumber: Diolah}

Tabel 4.3 merupakan hasil perhitungan presentase untuk melihat kesesuaian kriteria pembukuan penatausahaan aset tetap kendaraan dinas melalui SIMDA BMD dengan Permendagri No. 19 Tahun (2016). Berdasarkan hasil analisis kriteria pembukuan yang telah dilakukan menunjukkan 13 kriteria terpenuhi dari total 8 kriteria terkait pembukuan

$$
\begin{aligned}
\text { Tingkat Kesesuaian }= & \frac{\text { total skor yang diperoleh }}{\text { total kriteria }} \times 100 \% \\
& =\frac{8}{13} \times 100 \% \\
& =62 \%
\end{aligned}
$$

Presentase yang diperoleh terkait tingkat kesesuaian pembukuan terhadap Pemendagri No.19 Tahun 2016 diperoleh hasil bahwa tingkat kesesuaiannya terhadap peraturan sebesar $62 \%$ atau masuk dalam kategori "sesuai" dengan aturan. Penyebab ketidaksesuaian sebesar $38 \%$ disebabkan:

1. Dokumen kendaraan hibah tidak lengkap sehingga sulit untuk melakukan pembukuan sesuai aturan, pengurus barang belum melakukan pendaftaran.

2. Pengurus barang (bendahara barang OPD) belum melakukan pencatatan sesuai 
dengan format KIB dan tidak semua KIB menggambarkan bukti fisik aset tetap kendaraan dinas.

3. Keterbatasan Sumber Daya dalam hal ini keterbatasan Pengurus Barang pada masing-masing OPD yang belum dengan fasih menggunakan aplikasi SIMDA BMD sehingga proses pembukuan atau pencatatan ke dalam KIB dalam bentuk aplikasi menjadi lamban.

\section{Inventarisasi}

Menurut Permendagri No.19 Tahun 2016, inventarisasi merupakan kegiatan atau tindakan untuk melakukan perhitungan, pengurusan, penyelenggaraan, pengaturan, pencatatan data dan pelaporan barang milik daerah dalam unit pemakian. Badan Pengelola Keuangan dan Aset Daerah sendiri melakukan kegiatan inventarisasi aset tetap kendaraan dinas melalui prosedur:

a. Perencanaan kebutuhan dan penganggaran, karena melalui prosedur ini BPKAD dapat melihat berapa jumlah kebutuhan aset tetap kendaraan dinas yang diperlukan OPD Pemerintah Kota Jayapura. Standar Sarana dan Prasarana yang digunakan BPKAD untuk pemenuhan kebutuhan aset tetap kendaraan dinas Pemerintah Kota Jayapura diatur dalam Permendagri No.19 Tahun 2016 dan Permenpan No. 48 Tahun 2013. Namun, berdasarkan penelitian yang dilakukan pada BPKAD Kota Jayapura, belum sepenuhnya menggunakan Standar dan Sarana Prasana Operasional dalam Permendagri No.19 Tahun 2016, yang mengatur untuk pejabat eselon II, eselon III, dan eselon IV jenis kendaraan apa yang harus dipakai, mereknya dan "cc-nya" yang diatur juga dalam PP No. 6 Tahun 2006. Akan tetapi, faktor keterbatasan anggaran juga mempengaruhi sehingga tidak semua pejabat di lingkungan Pemerintah Kota Jayapura mendapatkan kendaraan dinas. 
Hal ini sesuai dengan pernyataan Sekretaris BPKAD dalam kutipan wawancara sebagai berikut;

“dalam perencanaan juga kita musti kira-kira kendaraan yang kita butuhkan di pemerintah kota itu ada berapa? Misalanya tahun ini mau beli berapa? Memang kalau kita sesuaikan dengan standar sarana dan prasarana pemerintah untuk pejabat eselon II, III, dan IV ada standar yang digunakan untuk kendaraan apa yang mereka harus pakai misalnya eselon IV motor 150 cc, eselon III 1.500 cc dan eselon II 2.000 atau 2.500 cc tetapi kita juga menyesuaikan dengan kemampuan anggaran daerah." (IP2-L11-19)

b. Pengadaan dan pendistribusian aset tetap kendaraan dinas pada Pemerintah Kota Jayapura berdasarkan perintah Walikota harus terpusat melalui BPKAD berdasarkan surat masuk dari sekretaris atau pimpinan yang kemudian dibuat rekapitulasi kebutuhan kendaraan dinas berdasarkan permintaan OPD, kecuali kendaraan teknis seperti mobil pemadam kebakaran, mobil puskesmas keliling, mobil keliling di DISPENDA dan beberapa OPD teknisi lainya, pengadaannya dikembalikan pada OPD yang bersangkutan karena OPD tersebut lebih mengetahui sepesifikasi dan kebutuhan dari kendaraan tersebut. Namun, secara aturan OPD tersebut harus tetap memberikan laporan kepada BPKAD dalam hal ini bagian pengadaan dan distribusi. Hal ini sesuai dengan pernyataan informan sebagai berikut.

"Berdasarkan surat, memang kita tidak turun langsung untuk cek, eselon ini belum dapat, tapi terkadang kita dapat informasi dari sekretaris atau pimpinannya langsung kalau ini belum dapat, makanya kita usulkan kemudian kita rekap baru yang bisa kita adakan kita adakan laporkan ke pimpinan jadi keputusan terakhir ada dipimpinan."(IP2L37-42)

Badan Pengelolaan Keuangan dan Aset Daerah Pemerintah Kota Jayapura sendiri mempunyai Perda Pokok-Pokok Pengelolaan Aset Daerah yang baru disosialisasikan di bulan Agustus 2017. Perdanya berdasarkan Permendagri No. 19 Tahun 2016, yang mengatur tugas pengadaan dan pendistribusian aset tetap kendaraan dinas. Badan Pengelola dan Keuangan Aset Daerah Kota Jayapura dalam melaksanakan tugasnya bertanggung jawab dari perencanaan anggaran 
untuk pembelian kendaraan berdasarkan petunjuk dari kepala daerah dengan melihat permintaan bahwa OPD minta kendaraan ini untuk kepentingan ini ketika disetujui dibuat dalam bentuk perencanaan anggaran dibeli, kemudian diserahkan kepada pengguna. Tanggung jawab BPKAD sebagai penyedia barang selesai dan hanya menjadi pengawas untuk mengawasi aset tetap kendaraan dinas, menyimpan dokumen, mengarsipkan dan administrasinya. Pengguna kendaraan dinas bertanggung jawab untuk perawatan, pemeliharaan sampai dengan penghapusan. Hal ini sesuai dengan pernyataan wawancara Kabid Aset sebagai berikut.

"Kita di sini punya Perda Pokok-Pokok Pengelolaan Aset Daerah cuma kemarin koordinasi dengan Kabag Umum itu harus direvisi Perdanya berdasarkan Permendagri No.19 Tahun 2016. Perda itu mengatur tugas pengadaan kendaraan, kami distribusikan juga berdasarkan petunjuk kepala daerah, sehingga tidak menjadi kewenangan mutlak kami sebagai penyedia untuk mendistribusikan baik kami maupun kepala BPKAD tapi kami minta petunjuk kepala daerah." (IP4-L91-98).

"Dari proses perencanaan sampai dengan pengadaan kami minta petunjuk dari kepala daerah berdasarkan permintaan bahwa dinas ini minta kendaraan ini untuk kepentingan ini, setelah disetujui kepala daerah kami buat dalam perencanaan anggaran, kami beli setelah kami beli kendaraan itu kami serahkan kepada pengguna, tanggung jawab kami sebagai penyedia barang selesai, setelah itu kami hanya menjadi pengawas mengawasi kendaraan dinas, menyimpan dokumen, mengarsipkan dan administrasinya. Pengguna bertanggung jawab untuk perawatan dan pemeliharaan tersebut sampai kepada penghapusan." (IP-L61-67)

c. Proses Pembelian aset tetap kendaraan dinas pada Pemerintah Kota Jayapura menggunakan E-Katalog, yang merupakan Standar Kebijakan Harga oleh Lembaga Kebijakan Pengadaan Barang/Jasa Pemerintah (LKPP) berdasarkan Peraturan Presiden No. 106 Tahun 2014 dan Peraturan Presiden No. 157 Tahun 2014.

E-Katalog ini sangat berperan penting dalam standar penetapan harga kendaraan dinas, yang mana harga kendaraan dinas berlaku sama untuk semua wilayah Indonesia. Dengan demikian, dapat mengurangi tindakan korupsi baik dari pihak pengadaan dalam ini BPKAD maupun pihak ke tiga dalam ini perusahaan, karena ini akan jadi temuan BPK ketika ada pihak yang ingin manipulasi harga kendaraan dinas. Hal ini sesuai dengan pernyataan wawancara Kasubbid 
Pengadaan dan Distribusi sebagai berikut:

"kita sekarang mengikuti aturan dari pusat dari KPP yang dimana sudah ada E Katalog untuk kendaraan dinas, jadi kita berpatokan pada E Katalog itu. Dengan demikian, E Katalog itu keluar dengan harga mobilnya sekian itu yang kita pakai, kita tidak bisa bilang tolong harga mobilnya naik sedikit biar ada manipulasi, karena itu akan jadi temuan untuk BPK jadi bukan kami saja yang akan diperiksa oleh BPK tapi pihak perusahaan juga akan diperiksa." (IP4L113-121)

d. Surat Tanda Nomor Kendaraan (STNK) dan Bukti Pemilik Kendaraan Bermotor (BPKB) ialah dokumen aset tetap kendaraan dinas yang wajib dilaporkan oleh pengguna kepada BPKAD. Pada Pemerintah Kota Jayapura, aset tetap kendaraan dinas dapat diperoleh dengan cara pembelian langsung dari BPKAD dan bantuan dari pusat yang disebut hibah. Jadi, untuk pembelian aset tetap kendaraan dinas secara langsung harus disertai dokunen berupa Berita Acara Serah Terima Barang (BAST) dan Kontrak, dan untuk bantuan hibah harus disertai dokumen Berita Acara Serah Terima Barang (BAST) dan Naskah Perjanjian Hibah Daerah (NPHD).

Dengan adanya dokumen ini maka Pemerintah Kota Jayapura dapat mengakuinya sebagai aset tetap milik Pemerintah Kota Jayapura. Oleh karena itu, dokumen aset tetap kendaraan dinas yang lengkap dapat menggunakan biaya pemeliharan yang ada pada DPA masing-masing OPD untuk pemeliharaan kendaraan baik perpanjangan STNK, perawatan mesin kendaraan dan bahan bakar kendaraan. Hal ini sesuai dengan pernyataan wawancara Kabid Aset sebagai berikut.

"OPD menerima bantuan hibah berupa aset tetap kendaraan dinas, dokumennya harus lengkap, ada berita acaranya, ada NPHD. Dengan demikian, berdasarkan berita acara dan NPHD kita akui sebagai barang milik Pemerintah Kota Jayapura." (IP3- L74-78)

Terkait peran biaya pemeliharaan, hal yang sama juga dikemukakan dalam wawancara Kabid Aset sebagai berikut.

“Yang bertanggung jawab tidak hanya BPKAD tapi OPD yang menerima kendaraan dinas 
juga harus bertanggung jawab karena mereka adalah pengguna kendaraan dinas. BPKAD hanya sebgai administrasi yang mencatat. OPD harus bertanggung jawab terkait pemeliharaan, perpanjang STNK." (IP3-L108-110)

e. Penghapusan barang milik daerah berdasarkan Permendagri No. 19 Tahun 2016 adalah tindakan penghapusan barang pengguna/kuasa pengguna dan penghapusan dari daftar inventaris barang milik daerah. Penghapusan barang bergerak seperti aset tetap kendaraan dinas dapat dilakukan dengan pertimbangan teknis, yaitu: secara fisik barang tidak dapat digunakan karena rusak berak dan tidak ekonomis bila diperbaiki. Penghapusan kendaraan dinas pada Pemerintah Kota Jayapura dilakukan pada kendaraan dinas yang sudah berumur diatas 10 (sepuluh) tahun pada kendaraan yang sudah tua, sebelum melakukan penghapusan atas aset tetap kendaraan dinas, kondisi kendaraan terlebih dahulu di cek, kemudian dibuatkan SK Penghapusan dan diajukan ke DPRD. Penghapusan tersebut diatas dilakukan setelah mendapat persetujuan kepala daerah dan penetapan oleh Pengelola atas nama Kepala Daerah. Hal ini sesuai dengan pernyataan wawancara Kepala Inspektorat sebagai berikut.

“Kita cek lagi lalu kita SK-kan kemudian diajukan ke DPRD, jika ada persetujuan dihapus “Ok" kita lakukan penghapusan tapi kita cek lagi kondisi kendaraan tersebut, apakah rusak atau tidak, jika diatas 10 (sepuluh) tahun, perawatan sulit kita dum saja atau kita jual ke yang bersangkutan dengan demikian tidak memberatkan biaya pemeliharaannya." (IP1-L56-62)

Pemerintah Kota Jayapura sedang melakukan upaya penghapusan aset tetap kendaraan dinas dengan membangun kerjasama dengan Kantor Pelayanan Kekayaan Negara dan Pelelangan (KPKNL). Jadi, Kantor Pelayanan Kekayaan Negara dan Pelelangan adalah kantor yang mempunyai kemampuan dibidang penilaian barang, dimana semua jenis barang milik daerah Pemerintah Kota Jayapura yang akan dihapus baik kendaraan dinas maupun aset lainnya, nilai jualnya akan ditentukan KPKNL dan sekarang dalam tahap evaluasi berkas 
STNK dan BKPB. Hal ini sesuai dengan pernyataan Kabid Aset dalam wawancara sebagai berikut.

"Kita sedang upayakan melakukan penghapusan, sekarang kami membangun kerja sama dengan KPKNL melakukan pelelangan, sekarang dalam tahap kita mengevaluasi berkas, berkas yang dimaksud adalah STNK dan BPKP." (IP3-L22-26)

f. Pelaksanaan sensus aset tetap kendaraan dinas pada Pemerintah Kota Jayapura dilaksanakan oleh BPKAD dengan bantuan BPK dan Inspektorat Kota Jayapura melalui apel kendaraan dinas untuk mendapatkan data barang yang benar dan dapat dipertanggungjawabkan serta akurat (up to date), harus melalui sensus barang milik daerah. Tahap persiapan dan pelaksanaan, dimana masing-masing pengguna/kuasa pengguna harus melaksanakan pengisian formulir Buku Inventaris merupakan bagian dari pelaksanaan sensus asset tetap.. Tahun 2014 dilakukan pendataan kendaraan dinas dan ditemukan banyak kendaraan dinas yang tidak tercatat dan bukti fisik di lapangan tidak ditemukan, sehingga menjadi temuan oleh BPK. Dengan demikian, Badan Pengelola Keuangan dan Aset Daerah kembali melakukan penatausahaan aset tetap kendaraan dinas dengan melakukan penarikan kembali kendaraan dinas dari pengguna yang sudah pensiun atau mutasi, selain itu BPKAD juga melakukan peningkatan manjemen aset. Hal ini senada dengan tanya-jawab Kasubbid Pengadaan dan Distribusi sebagai berkut:

"Pernah diadakan sensus tahun 2014 untuk kendaraan dinas dan itu jumlahnya 375 (tiga ratus tujuh puluh lima) kendaraan yang terdata, itu yang baik dan yang masih bisa digunakan oleh Pemerintah Kota, sedangkan 83 (delapan puluh tiga) kendaraan roda 2 (dua), 4 (empat) dan 6 (enam) sudah rusak berat, jadi total kendaraan Pemerintah Kota saat itu 400 (empat ratus) lebih." (IP4-L38-44)

\section{Pelaporan}

Pelaporan ialah kegiatan yang dilakukan oleh kuasa pengguna/pengguna bersama pengurus barang untuk menyusun laporan kuasa pengguna barang 
semesteran, tahunan dan 5 (liima) tahun. Teknis pelaporan dilakukan secara berjenjang dan berkala sesuai dengan periode pelaporan akuntansi. Pembantu pengelola (BPKAD) megumpulkan semua laporan pengguna barang dari masingmasing OPD serta dibuat rekapitulasinya yang akan digunakan sebagai bahan penyusun neraca daerah. Hasil sensus barang dari setiap pemakai/kuasa pengguna, dicatat ke dalam buku inventaris dan disampaikan kepada pengelola (Sekretaris Daerah), selanjutnya merekap buku tersebut menjadi buku induk inventaris oleh pembantu pengelola (BPKAD). Berdasarkan interviu Kepala Inspektorat sebagai berikut.

"Masing-masing OPD sebagai penanggung jawab aset, penanggung jawab anggaran harus memberikan laporan yang riil, kepada bagian BPKAD." (IP1-L89-92)

Berdasarkan hasil perhitungan presentase untuk melihat kesesuaian kriteria pelaporan penatausahaan aset tetap kendaraan dinas melalui SIMDA BMD dengan Permendagri No. 19 Tahun 2016 sebagai berikut.

Tabel 4.5 Hasil Pengukuran Kesesusaian Pelaporan

\begin{tabular}{|c|c|c|c|c|}
\hline No & Kriteria Pelaporan & Ada & $\begin{array}{l}\text { Tidak } \\
\text { Sesuai }\end{array}$ & Teknik \\
\hline 1. & $\begin{array}{l}\text { BPKAD memiliki daftar usulan barang yang } \\
\text { dihapus. }\end{array}$ & & 0 & \\
\hline 2. & $\begin{array}{l}\text { Kepala OPD selaku Pengguna barang, } \\
\text { sudah membuat dan menyampaikan } \\
\text { laporan atas mutasi kepada pembantu } \\
\text { pengelola barang. }\end{array}$ & 1 & & \\
\hline 3. & $\begin{array}{l}\text { Daftar mutasi barang yang dilaporkan oleh } \\
\text { pengguna kuasa barang sudah } \\
\text { menjelaskan alasan penyebab bertambah } \\
\text { an berkurangnya BMD. }\end{array}$ & 1 & & \\
\hline 4. & $\begin{array}{l}\text { Pengguna/kuasa pengguna } \text { barang } \\
\text { menyampaikan laporan pengguna barang } \\
\text { semesteran, tahunan dan } 5 \text { tahun kepada } \\
\text { pengelola BMD melalui pembantu } \\
\text { pengelola BMD. }\end{array}$ & & 0 & \\
\hline 5. & $\begin{array}{l}\text { Mutasi barang bertambah dan barang yang } \\
\text { bertambah dicatat secara tertib pada daftar } \\
\text { mutasi barang. }\end{array}$ & & 0 & \\
\hline 6. & $\begin{array}{l}\text { Pembantu pengelola (bagian aset) memiliki } \\
\text { rekapitulasi daftar mutasi barang. }\end{array}$ & 1 & & \\
\hline 7. & $\begin{array}{l}\text { Pembantu pengelola (bagian aset) memiliki } \\
\text { daftar usulan barang barang yang akan } \\
\text { dihapus }\end{array}$ & & 0 & \\
\hline 8. & Pelaporan BMD memiliki kelengkapan data & 1 & & \\
\hline
\end{tabular}




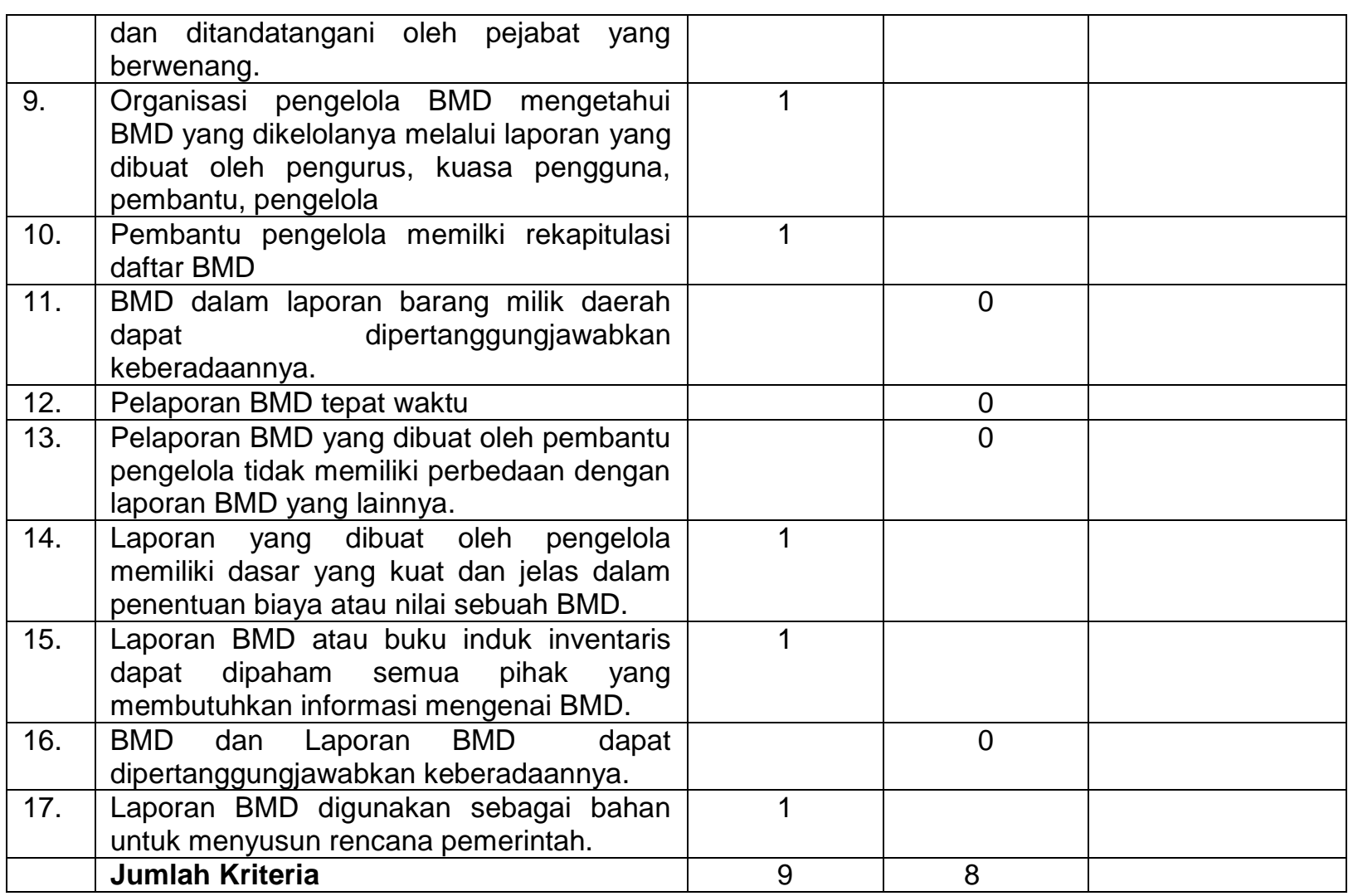

Berdasarkan hasil analisis kriteria pelaporan yang telah dilakukan yaitu 17 kriteria terpenuhi dari total 9 kriteria terkait pelaporan

$$
\begin{aligned}
\text { Tingkat Kesesuaian }= & \frac{\text { total skor yang diperoleh }}{\text { total kriteria }} \times 100 \% \\
& =\frac{9}{17} \times 100 \% \\
& =53 \%
\end{aligned}
$$

Presentase yang diperoleh terkait tingkat kesesuaian pelaporan terhadap Pemendagri No.19 Tahun 2016 diperoleh hasil bahwa tingkat kesesuaiannya terhadap peraturan sebesar $53 \%$ atau masuk dalam kategori "cukup sesuai" dengan aturan. Penyebab ketidaksesuaian sebesar $47 \%$ disebabkan pengguna/kuasa barang tidak menyampaikan laporan pengguna barang kepada BPKAD, pencatatan mutasi barang dan kurang tertib, BPKAD tidak memiliki daftar usulan barang yang akan dihapus dan beberapa barang milik daerah berupa aset tetap kendaraan dinas 
tidak dapat dipertanggungjawabkan.

Total keseluruhan tingkat kesesuaian penatausahaan aset tetap kendaraan dinas meliputi pembukuan, inventarisasi dan pelaporan sebagai berikut;

$$
\begin{aligned}
\text { Tingkat Kesesuaian } & =\frac{\text { total skor yang diperoleh }}{\text { total kriteria }} \times 100 \% \\
& =\frac{38}{54} \times 100 \% \\
& =70 \%
\end{aligned}
$$

Total presentase yang diperoleh terkait tingkat kesesuaian pembukuan, inventarisasi dan pelaporan terhadap Pemendagri No.19 Tahun 2016 diperoleh hasil bahwa tingkat kesesuaiannya terhadap peraturan sebesar $70 \%$ atau masuk dalam kategori "sesuai" dengan aturan dan penyebab ketidaksesuaian sebesar $30 \%$.

\section{Penyebab Permasalahan Aset Tetap Kendaraan Dinas Kota Jayapura}

Permasalahan aset tetap kendaraan dinas pada Pemerintah Kota Jayapura mengakibatkan kerugian ekonomi sebesar Rp.6.628.610.300,00. Dengan demikian dapat memberikan dampak negatif ekonomi yaitu pemborosan anggaran karena penggunaan kendaraan dinas tidak tepat sasaran. Sebaliknya apabila dilakukan peningkatan penatausahaan aset tetap kendaraan sebaik mungkin akan memberikan pengaruh postif terhadap aset tetap kendaraan dinas yang ada pada Pemerintah Kota Jayapura maka dapat meningkatkan kualitas laporan keuangan Pemerintah Kota Jayapura. Kegiatan ini dimaksud mendapatkan informasi yang tepat, lengkap dan muktahir mengenai kekayaan aset wilayah yang dikuasai pemerintah daerah. Berdasarkan hasil hasil analisis wawancara yang dilakukan, ringkasan temuan penelitian terkait permasalahan yang dihadapi BPKAD dalam penatausahaan aset tetap kendaraan milik Pemda, yang menjadi penyebab permasalahan dalam penatauasahaan aset tetap kendaraan dinas melalui SIMDA BMD sebagai berikut: 


\section{Administrasi}

Ketertiban administrasi harus disadari oleh pengguna aset tetap kendaraan dinas agar membantu BPKAD dalam penatausahaan aset tetap kendaraan dinas Pemerintah Kota Jayapura dalam pelaporan, peneliti menemukan administrasi kendaraan dinas pada Pemerintah Kota Jayapura belum tertib, disebabkan oleh beberapa faktor sebgai berikut: Ketidaklengkapan Dokumen Penunjang Laporan Aset. Hal ini sesuai dengan pernyataan wawancara Kasubbid Analisa Kebutuhan dan Inventarisasi sebagai berikut.

"Hibah ini yang masih menjadi kendala bagi kami juga, seringkali dokumen-dokumennya tidak lengkap, kadang tidak ada Karena sering teman-teman di OPD mendapat bantuan kedaraan dari kementerian atau pemerintah pusat mereka sendiri yang mengurusnya ke sana, mereka yang memperjuangkannya setelah mendapat bantuan mereka tidak melaporkannya ke BPKD dalam hal ini BPKAD." (IP4-L189-195)

\section{Keuangan}

Peneliti menemukan bahwa kondisi anggaran pada Pemerintah Kota Jayapura memiliki pengaruh terhadap proses penatausahaan aset tetap kendaraan dinas. Kondisi-kondisi keuangan yang menyebabkan permasalahan penatausahaan aset tetap dibagi menjadi beberapa bagian sebagai berikut:

\section{a. Keterbatasan Anggaran}

Seperti yang diketahui berdasarkan aturan Standar Sarana dan Prasarana Operasional yang seharusnya semua pejabat eselon pada Pemerintah Kota Jayapura harus memiliki kendaraan dinas dalam melaksanaakan tugas, belum bisa terpenuhi oleh BPKAD karena keterbatasan anggaran. Hal tersebut sesuai dengan pernyataan wawancara Kepala Inspektorat sebagai berikut;

“Jadi setiap tahun kita rencanakan, biasanya kita punya data base setiap pejabat, yang mana setiap pejabat itu harus punya kendaraan dinas ada juga kendaraan operasional. Sesuai aturan juga pejabat eselon IV harus punya kendaraan dinas, kalau kita ikut semua yang sesuai aturan kita tidak punya sumber dana yang besar untuk menyelesaikan semua." (IP1-L172-179) 


\section{b. Pelimpahan dan Penyalahgunaan Anggaran Biaya Pemeliharaan}

Hal ini sesuai dengan pernyataan wawancara Kabid Aset sebagai berikut.

“ada tunggakan-tunggakan kendaraan yang seharusnya dibayar OPD bukan BPKAD tapi ujung-ujungnya dibuang di BPKAD sedangkan BPKAD tidak ada anggaran untuk itu, anggaran untuk pemeliharaan ada di masing-masing OPD, seharusnya OPD yang bertanggung jawab, makanya dalam DPA dianggarkan ada biaya pemeliharaan, biaya pengurusan STNK disini yang biasa OPD lalai." (IP3-L113-120)

\section{c. Penunggakan pembayaran penjualan kendaraan dinas}

Berdasarkan penelitian ditemukan ada sejumlah kendaraan dinas mengalami penunggakan pembayaran dikarenakan pemindatangan aset tetap kendaraan yang tidak termonitor dan belum melakukan TP-TGR yang ditetapkan oleh peraturan perundang-undangan sehingga menjadi temuan dan catatan di SK Penjualan kendaraan dinas ada pegawai yang mencicil tapi macet. Hal ini sesuai dengan pernyataan wawancara Kepala Inspektorat sebagai berikut.

“Selama ini yang menjadi temuan dan catatan di SK Penjualan kendaraan dinas, ada yang dicicil berapa kali ada yang sedikit macet, itulah yang menjadi catatan dan angkanya ada di BPKAD, setiap tahun ini yang mejadi catatan." (IP1-L163-167)

\section{Birokrasi}

\section{a. Ketiadaan Payung Hukum}

Sampai saat ini Pemerintah Kota Jayapura belum memiliki Peraturan Walikota sendiri yang dapat membuat aturan khusus terhadap penatausahaan aset tetap kendaraan kantor. Dengan tidak adanya peraturan khusus menyebabkan penyalahgunaan aset tetap kendaraan dinas di luar jam dinas atau digunakan tidak tepat waktu sehinngga dapat menimbulkan kerusakan. Sesuai dengan pernyataan wawancaran Kasubbid Pengadaan dan Distribusi sebagai berikut.

"Pengunaan kendaraan dinas ini harus dibuat aturan khusus dalam hal ini mungkin kita buat Perwal yang mengatur tentang jam operasional kendaraan-kendaraan dinas, jadi jam-jam tertentu kendaraan dinas boleh keluar, seperti contoh jam kerja sampai jam 5 sore lewat dari jam ini mobil-mobil dinas tidak boleh berkeliaran dengan ini mungkin bisa tertib." (IP4-L291-298). 


\section{b. Keterbatasan Tanggung Jawab BPKAD}

Dalam hal perencanaan dan pengadaan aset tetap kendaraan dinas pada Pemerintah Kota Jayapura, BPKAD mendapat warning khusus dari BPK terkait pelaksanaan perencanaan, dikarenakan belum mampu melakukan perencanaan selama 5 (lima) tahun, perencanaan selama ini hanya dilakukan berdasarkan surat pemintaan terakit kemampuan anggaran. Seperti penyataan wawancara Kabid Aset sebagai berikut.

“Pada saat pemeiksaan BPK tahun 2013, ada sedikit warning masukan dari BPK kepada kami sehingga pelaksanaan kalau bisa harus direncanakan, perencanaan 5 (lima) tahun kedepan, misalnya: motor saya mau pengadaan 100 (seratu) unit bearti setiap tahun 20,20, 20 sampai dengan 100 (seratus) unit, begitu juga dengan mobil, tapi saya katakan kepada BPK bahwa kita selalu mengadakan pengadaan berdasarkan permintaannya sekian itu yang kita beli dan kembali kita sesuaikan dengan kemampuan keuangan daerah dalam hal ini ketersediaan dana yang tersedia. Tapi BPK katakan tidak bisa begitu harus ada perencanaan 5 (lima) tahun." (IP4-L50-60)

\section{c. Pengadaan kendaraan yang tidak terpusat}

Pengadaan kendaraan yang tidak terpusat menyebabkan masalah dalam kelengkapan dokumen aset. Dengan demikian, membuat BPKAD sulit untuk mempertangungjawabakan semua dokumen aset tetap kendaraan dinas, karena sebagian OPD melakukan pengadaan sendiri ke pusat tanpa melaporkan atau menyerahkan bukti berupa dokumen kepada BPKD sebagai pembantu pengelola aset tetap kendaraan dinas. Hal itu sesuai dengan wawancara Sekretaris BPKAD sebagai berikut.

“kalau pengadaan kendaraan biasanya di sini, tapi ada beberapa OPD yang mengadakan kendaraan dan itu kita minta untuk mereka selesai mengadakan kendaraan harus melapor dengan memberikan BPKB kendaraan itu sehingga kita bisa mengetahui kendaraan ini yang dibeli di tahun ini ada di sini dan dokumen BPKB itu memang kita yang minta untuk disimpan di keuangan (BPKAD), sehingga kita bisa mengetahui kendaraan yang diadakan diluar BPKAD, ada yang kadang mereka beli sendiri tapi datang tanya di sini sedangkan dokumen belum kamu berikan ke sini (BPKAD) tapi datang tanya di sini." (IP2-L89-90).

\section{Sumber Daya Manusia}

\section{a. Tingkat mutasi pegawai}


Tingkat mutasi pegawai yang terjadi di birokrasi Pemerintah Kota Jayapura menyebabkan penatausahaan aset tetap kendaraan dinas menjadi tidak tertib karena pada saat terjadi mutasi pegawai kendaraan dinas juga ikut mutasi dan hanya pegawai yang memiliki kesadaran saja yang mau melapor ke BPKAD. Hal tersebut sama dengan pernyataan wawancara Kepala Inspektorat sebagai berikut.

"Terkadang ini menjadi masalah juga karena birokrasi di sini melakukan mutasi pegawai, hal ini menyebabkan pencatatan tidak tertib, ketika pegawai di dinas A pindah ke dinas $B$, kendaraan itu ikut dibawah saat pindah ke dinas $C$ kendaraan ikut pindah juga. Kejadian seperti ini yang belum terukur pencatatan di KIBnya, sehingga kita sering sarankan kepada pimpinan OPD agar melakukan pencatatn dengan baik." (IP1-L101-107).

\section{b. Keterbatasan keahlian manusia}

Keterbatasan sumber daya manusia yang terlibat dalam kegiatan penatausahaan aset tetap kendaraan dinas masih rendah, dalam penggunaan aplikasi SIMDA BMD di masing-masing OPD dikarenakan ada sebagian bendahara barang yang bisa mengoperasikan komputer dan ada yang tidak bisa menggunakan komputer sehingga memperlambat penyelesaian laporan KIB aset tetap kendaraan dinas, yang seharusnya BPKAD hanya menerima data terpaksa harus menginput ulang KIB dari OPD yang bersangkutan. Berdasarkan wawancara Sekretaris BPKAD sebagai berikut.

"sumber daya untuk bendahara barang di masing-masing OPD juga sangat terbatas sudah dikasih tugas untuk menginventaris barang tapi kenyataan BPKAD yang kejar-kejar bahkan KIBnya kami yang buat, padahal itu tugas bendahara barang di OPD. (IP2-L172177).

\section{Sistem Informasi}

Peneliti menemukan bahwa sistem informasi "SIMDA BMD" yang dipakai oleh Pemerintah Kota Jayapura dalam kegiatan tata usaha aset tetap sarana dinas memiliki keterbatasan sehingga memperlambat pelaporan aset tetap, disebabkan oleh beberapa faktor sebagai berikut: 


\section{a. SIMDA BMD masih menggunakan sistem off-line}

SIMDA masih menggunakan sistem off-line, metode koneksi aplikasi SIMDA BMD versi 2.7 antara BPKAD dan OPD masih secara off-line, di mana BPKAD menyiapkan server dan beberapa Clinet OPD menginput data ke BPKAD. Dengan demikian, setiap bendahara barang OPD menginput barang di SIMDA BMD dan diharuskan menyerahkan laporan ke petugas SIMDA BMD di BPKAD bagian aset.

b. SIMDA BMD tidak terintegrasi dengan bagian keuangan.

Pada Pemerintah Kota Jayapura belum terintegrasi ke bagian keuangan, hanya di bidang aset pada BPKAD sehingga SIMDA masih kurang optimal penggunaannya karena data yang didapat belum sepenuhnya update sesuai laporan keuangan. Data yang didapat seringkali kurang akurat karena SIMDA BMD tidak dapat diakses secara onliene sehingga kurang cepat dalam pengaksesan informasi. Dari pernyataan Kepala Inspektorat sebagai berikut.

"Setelah data dimasukan kemudian log in lagi, karena aplikasi ini up date terus baru bisa digunakan dan masih menggunakan sistem off -line, penginputan dilakukan di masingmasing OPD kemudian hasil akhir berupa print out yang diserahkan kepada BPKAD bagian aset. Sehingga kemungkinan manipulasi data masih bisa terjadi karena baru terintegrasi dengan bagian aset belum dengan SIMDA BMD Keuangan". (IP1-L263-269).

\section{SIMPULAN}

Penelitian ini menelaah tentang analisis penatausahaan asset tetap kendaraan melalui system manajemen BMD dan pemicu masalah Aset Tetap Kendaraan Dinas Badan Pengelolah Keuangan dan Aset Daerah Pemerintah Kota Jayapura. Berdasarkan hasil analisis pada bab sebelumnya, maka kesimpulan penelitian ini sebagai berikut:

\section{Penatausahaan Aset Tetap Kendaraan Dinas Kota Jayapura}

Berdasarkan hasil analisis yang telah dilakukan, tingkat kesesuaian kegiatan 
tata kelola aset tetap kendaraan dinas di Pemerintah Kota Jayapura terdiri dari pembukuan, inventarisasi dan pelaporan sebesar $70 \%$ atau masuk dalam kategori "sesuai" dengan peraturan. Teknik yang digunakan ialah analisis deskriptif presentase dengan acuan Permendagri No. '19 Tahun 2016 tentang Pedoman Teknik Tata Kelola BMD. Aspek- aspek yang masih belum sesuai sebesar $30 \%$ ialah dokumen kendaraan hibah tidak lengkap, pencatatan KIB belum sesuai, pencatatan mutasi kurang tertib, BPKAD tidak memiliki daftar usulan barang yang dihapus dan beberapa harta tetap transportasi dinas tidak dapat dipertanggungjawabkan.

\section{Penyebab Permasalahan Penatausahaan Aset Tetap Kendaraan Dinas Kota Jayapura}

Permasalahan penatausahaan aset tetap kendaraan dinas dilihat dari 5 (lima) sisi, yaitu manajemen (administrasi), keuangan, birokrasi, SDM dan terbatasan penggunaan SIMDA BMD. Penyebab permasalahan pada bagian administrasi yaitu ketidaklengkapan berkas dan ketidakjelasan temuan penghapusan, penyebab sisi keuangan yaitu terbatasnya anggaran, pelimpahan dan penyalahgunaan anggaran biaya pemeliharaan, penyebab sisi birokrasi yaitu tidak adanya payung hukum, tanggung jawab BPKAD terbatas, Pengadaan kendaraan yang tidak tepat, penyebab sisi sumber daya manusia yaitu tingkat perpndahan pegawai dan keterbatasan sumber daya manusia dan penyebab keterbatasan penggunaan sistem informasi manajemen barang milik daerah yaitu SIMDA BMD masih menggunakan sistem offline dan SIMDA BMD pada Pemerintah Kota jayapura belum terintegrasi ke bagian keuangan BPKAD.

\section{DAFTAR PUSTAKA}

Denhardt, J. V. and R. B. D. (2003). The New Public Service.

Keban, Y. T. (2008). Enam Dimensi Strategis Administrasi Publik: Konsep, Teori dan 
Isu.

Peraturan Menteri Dalam Negeri Nomor 17 Tahun 2007 tentang Pedoman Teknis Pengelolaan Barang Milik Daerah, (2007).

Peraturan Menteri Dalam Negeri Nomor 19 Tahun 2016 tentang Pedoman Teknis Pengelolaan Barang Milik Daerah, (2016).

PP No.6/2006 tentang Pengelolaan Barang Milik Daerah, (2006).

Siregar, D. D. A. H. (2004). Manajemen Aset.

Undang-undang Nomor 23 Tahun 2014 tentang Pemerintah Daerah, (2014). 